\title{
Growth performance of thai pangus (pangasius hypophthalmus) in polyculture system using different supplementary feeds
}

\author{
M. A. B. Sayeed, G. S. Hossain, S. K. Mistry and K. A. Huq \\ Fisheries and Marine Resource Technology Discipline, Life Science School, Khulna University, Khulna-9208, Bangladesh.
}

\begin{abstract}
Thai pangus polyculture with carps has been increasing for its high potential, however very few attempts were made to compare its growth using different types of feed. A research was undertaken to assess the effect of three types of feed on growth of Thai pangus (Pangasius hypophthalmus) and rohu (Labeo rohita) in polyculture system for 11 months from 15 May 2005 to 15 April 2006 in Khulna. Growth performance using Hand-made Feed $\left(\mathrm{F}_{1}\right)$ was compared with two commercial fish feed, Sunney Feed $\left(\mathrm{F}_{2}\right)$ and Saudi-Bangla Feed $\left(\mathrm{F}_{3}\right)$ in three respective treatments of $T_{1}, T_{2}$ and $T_{3}$. All treatments were carried out in triplicate at 24700/ha for Thai pangus and 4940/ha for rohu. Average initial weight of Thai pangus and rohu were 4.5 and 33.5g respectively. Growth performance was influenced by feed type. Average final weight of Thai pangus and rohu were 820 and 710; 846 and 770; and 872 and 717g with specific growth rate 1.58 and 0.93; 1.59 and 0.95 and 1.60 and $0.93 \%$ day ${ }^{-1}$ in $T_{1}, T_{2}$ and $T_{3}$ respectively. Feed conversion ratio was estimated 2.3 in $\mathrm{T}_{1}, 2.1$ in $\mathrm{T}_{2}$ and 1.96 in $\mathrm{T}_{3}$. The result showed a typical increasing trend of final weight and specific growth rate of Thai pangus along with the increasing of feed protein level. But rohu showed highest growth in $\mathrm{T}_{2}$ where protein level was $26-30 \%$ which was lower than that of $\mathrm{T}_{3}$ (Protein level 28-32\%). The study suggests that suitable protein level and quality feed is required for adequate growth of fish.
\end{abstract}

Key words: Feed, Thai pangus, Polyculture, Growth.

\section{Introduction}

In Bangladesh, about $63 \%$ animal protein of our meal comes from fisheries resources (Ahmed, 2005) which are composed of 260 freshwater native species, 12 species of exotic fishes, 24 species of freshwater prawn, 475 marine fish species and 36 species of marine shrimp (Haque, 2005). Sarker (2000) reported that amongst exotic fish species Thai pangus (Pangasius hypophthalmus) is the best due to its easy culture system, favorable weather condition for culture and high market demand. According to Sarder et al. (1994), pond culture of native pangus ( $P$. pangasius) was started in 1945 at Khulna region of Bangladesh. But due to the lack of specific technical know-how as well as proper culture management it was neither successful nor so popular to the local people. Although necessary steps for native pangus culture in closed water condition were taken in 1987 at Chandpur, but the initiative did not face any notable success (Sarker, 2000). After the failure of native pangus culture the government of Bangladesh imported 100 numbers fry (0.18 g weighted) of Thai pangus ( $P$. hypophthalmus) from Thailand in 1990 (Sarker, 2000). In recent years, Thai pangus has become one of the most popular commercial culturable species due to its high yield and low production cost, and many hatcheries all over the country are now producing Thai pangus fry to meet up the farmers' demand. Depending on availability of fry the monoculture system of Thai pangus has widely been spreaded throughout the country. Now the fish farmers are also too much interested to culture Thai pangus. Outside Bangladesh, three important species viz. $P$. hypophthalmus, $P$. larnaudi and $P$. sanirwangsei are cultured extensively in Thailand, Combodia and Vietnam both in earthen ponds (Bardach et al., 1972) and in floating net cages (Aguru, 1970) where it reaches up to 3 $\mathrm{kg}$ in two years. The survival rate of $P$. hypophthalmus is satisfactory, 85\%, stated by Rahman et al. (1992). High density and semi-intensive culture of $P$. hypophthalmus in ponds have been established and are very popular in Bangladesh. Such culture can produce at a rate of as high as 25-30 tons/ha/yr. with protein rich diets (BFRI and BARC, 2001).

To optimize the utilization of available resources, polyculture is the best and pond culture has presented this opportunity to Thai pangus-rohu polyculture. The productivity of the aquatic system is thus increased by more efficiently utilizing ecological resources within the environment. Stocking two or more complimentary fish species can increase the maximum standing crop of a pond by allowing a wide range of available food items and the pond volume to be utilized (Lutz, 2003). Though Thai pangus and rohu has different feeding habits, it has been seen that these species mostly prefer balanced diet (DoF, 2000). But only natural food cannot afford high production in commercial polyculture system and many literature reveal significantly higher growth rates and greater yields with the addition of supplemental feed (Green, 1992; Diana et al., 1994).

Thai pangus growers generally use different supplemental feeds in culture. The availability of reliable data regarding these additional feeds is important for rapid growth of Thai pangus in polyculture system. Determination of suitable type of feed based on reliable data may help to promote fish growth and production, thus increasing profitability. So the main objective of the present study was to check and compare the growth performance of Thai pangus ( $P$. hypophthalmus) polyculture using hand made and commercial feeds to get a better understanding of the feed requirements of that combination of fish species.

\section{Materials and methods}

The research was carried out in Batiaghata, Khulna in nine rectangular shaped earthen culture ponds (0.2 ha each) for 
11 months from 15 May 2005 to 15 April 2006. There were three treatments which were carried out in triplicate with a stocking density of $24700 /$ ha for Thai pangus ( $P$. hypophthalmus) and 4940/ha for rohu (L. rohita). The initial average weight of Thai pangus and rohu were 4.5 and $33.5 \mathrm{~g}$ respectively for all treatments. Three different types of feed - Hand Made Feed $\left(\mathrm{F}_{1}\right)$, Sunney Fish Feed $\left(\mathrm{F}_{2}\right)$ and Saudi Bangla Fish Feed $\left(\mathrm{F}_{3}\right)$ with different proximate compositions (Table-1) were used in three respective treatments of $T_{1}, T_{2}$ and $T_{3}$.

Table 1. Protein, Fat and Moisture level of Hand Made Feed $\left(F_{1}\right)$, Sunney Fish Feed $\left(F_{2}\right)$ and Saudi Bangla Fish Feed $\left(\mathrm{F}_{3}\right)$ with different feeding specifications

\begin{tabular}{|c|c|c|c|c|c|c|c|}
\hline \multicolumn{2}{|c|}{$\begin{array}{c}\text { Types } \\
\text { of Feed }\end{array}$} & $\begin{array}{l}\vec{\Phi} \\
\vdots \\
\vdots \\
\vdots\end{array}$ & 売 & =1 & 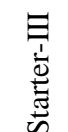 & 咅 & 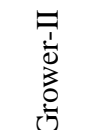 \\
\hline \multirow{3}{*}{ P (\%) } & $F_{1}$ & 28.61 & 28.61 & 28.61 & 23.9 & 23.9 & 23.9 \\
\hline & $F_{2}$ & 30 & 30 & 30 & 26 & 26 & 26 \\
\hline & $F_{3}$ & 32 & 32 & 32 & 28 & 28 & 28 \\
\hline \multirow{3}{*}{ F (\%) } & $F_{1}$ & 12 & 12 & 10 & 10 & 10 & 10 \\
\hline & $F_{2}$ & 5 & 5 & 5 & 5 & 5 & 5 \\
\hline & $\mathbf{F}_{3}$ & 5 & 5 & 5 & 5 & 4 & 4 \\
\hline \multirow{3}{*}{ M (\%) } & $F_{1}$ & 14 & 14 & 14 & 14 & 15 & 15 \\
\hline & $F_{2}$ & 11 & 11 & 11 & 11 & 11 & 11 \\
\hline & $\mathbf{F}_{3}$ & 12 & 12 & 12 & 12 & 12 & 12 \\
\hline \multirow{4}{*}{ 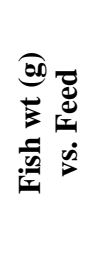 } & "च & 5 & 16 & 31 & 76 & 131 & 201 \\
\hline & E & -15 & -30 & -75 & -130 & -200 & above \\
\hline & $\Xi$ & 35 & 51 & 76 & 136 & 191 & 261 \\
\hline & ְि & -50 & -75 & -135 & -190 & -260 & $\begin{array}{c}- \\
\text { above }\end{array}$ \\
\hline \multirow{2}{*}{\multicolumn{2}{|c|}{ FR }} & & & & & & $2.5-$ \\
\hline & & $15-10$ & $10-8$ & $8-6$ & $6-4$ & $4-2.5$ & 1.5 \\
\hline
\end{tabular}

$\mathrm{P}=$ Protein, $\mathrm{F}=$ Fat, $\mathrm{M}=$ Moisture, $\mathrm{FR}=$ Feeding Rate $(\%$ of body wt), $\mathrm{FF}=$ Feeding Frequency $\left(\right.$ day $^{-1}$ )

Protein level ( $\mathrm{N}$ X 6.25) was determined by the Kjeldahl method after an acid digestion using an Auto Kjeldahl System (1030-Autoanalyser; Tecator, Hoganos, Sweden). Fat level was determined by the ether-extraction method by Soxtec System HT (Soxtec System HT6; Tecator, Hoganos, Sweden). Moisture content was determined by oven-drying at $105{ }^{\circ} \mathrm{C}$ for $24 \mathrm{~h}$ until a stable weight was attained.

Two commercial fish feed (Sunney Fish Feed - $\mathrm{F}_{2}$ and Saudi Bangla Fish Feed $-F_{3}$ ) were purchased from the local market. Hand Made Feed $\left(\mathrm{F}_{1}\right)$ was formulated and the ingredient composition is given in Table 2.

The experimental diets were supplied to the ponds at different feeding rates and frequencies according to their body weight (Table 1). The rates of supplied feeds were decreased with increased individual body weight of fish.
Fishes were randomly weighed once in every month and the daily ration was adjusted accordingly. Feed testing tray was used to avoid excess feed. Different water quality parameters viz. temperature, dissolved oxygen, $\mathrm{pH}$ were monitored fortnightly at 10-12 a.m.

Table 2. Hand Made Feed $\left(F_{1}\right)$ components and their protein levels for Starter and Grower Feed.

\begin{tabular}{cccc|cc}
\hline Feed & \multirow{2}{*}{$\begin{array}{c}\text { Actual } \\
\text { protein } \\
\text { Components }\end{array}$} & \multicolumn{2}{c|}{ Starter Feed } & \multicolumn{2}{c}{ Grower Feed } \\
\hline (\%) & used & $\begin{array}{c}\text { Protein } \\
\text { (\%) }\end{array}$ & $\begin{array}{c}\text { \% } \\
\text { used }\end{array}$ & $\begin{array}{c}\text { Protein } \\
\text { (\%) }\end{array}$ \\
\hline Meat/fish & 45 & 25 & 11.25 & 20 & 9.00 \\
meal & & & & & \\
Rice bran & 12 & 23 & 2.76 & 32 & 3.84 \\
Til oil cake & 26 & 20 & 5.20 & 18 & 4.68 \\
Soybean cake & 40 & 20 & 8.00 & 10 & 4.00 \\
Wheat flower & 14 & 10 & 1.40 & 17 & 2.38 \\
Vitamin & - & 0.1 & - & 0.1 & - \\
premix & - & 1 & - & 2 & - \\
Cod liver oil & - & 1 & - & 0.9 & - \\
Salt & - & 0.9 & - & \\
\hline Total & - & 100 & 28.61 & 100 & 23.90 \\
\hline
\end{tabular}

Growth performance and feed utilization efficiency were calculated according to Ricker (1975) as follows:

Specific Growth Rate (SGR \% day $\left.{ }^{-1}\right)=100\left[\left(\operatorname{lnW}_{\mathrm{t}}-\right.\right.$ $\left.\ln \mathrm{W}_{\mathrm{o}}\right) \mathrm{t}^{-1}$; ; where $\mathrm{W}_{\mathrm{o}}$ and $\mathrm{W}_{\mathrm{t}}$ are the initial and final live weight (g) of the fish respectively, and t is culture period in days.

*Feed Conversion Ratio (FCR = Dry Weight $(\mathrm{g})$ of Feed Supplied / Live Weight (g) of Fish Gained

\section{Results and Discussion}

Results of growth performance of Thai pangus (Pangasius hypophthalmus) polyculture using different supplementary feeds indicated significant effect of feed in different treatments. (Table 4). At the termination of 11 months feeding trial the average body weight of individual Thai pangus and rohu attained at 820, 710; 846, 770; and 872, $717 \mathrm{~g}$ with specific growth rate (SGR) 1.58, 0.93; 1.59, 0.95 and $1.60,0.93 \%$ day $^{-1}$ in $\mathrm{T}_{1}, \mathrm{~T}_{2}$ and $\mathrm{T}_{3}$ respectively. The values of feed conversion ratio (FCR) for the experimental fishes under $T_{1}, T_{2}$ and $T_{3}$ were estimated as 2.3, 2.1 and 1.96 respectively.

The result of the experiment reveals that significantly higher growth of Thai pangus (872 g) with the highest SGR $\left(1.60 \%\right.$ day $\left.^{-1}\right)$ was achieved when they were fed with higher crude protein level (32\% for fry and $28 \%$ for adult), and lower growth (820g) with the lowest SGR $\left(1.58 \%\right.$ day $\left.^{-1}\right)$ was obtained from lower protein level (28.61\% for fry and $23.90 \%$ for adult) utilization. Huq et

\footnotetext{
* Total feed (dry wt. in g) supplied to the biomass of a particular treatment in entire culture period was divided by the stocking density to get the average feed allocation per individual fish which was afterwards divided by average live wt. of fish gained to get the FCR of that treatment.
} 
al. (2004) found a higher growth $(502.77 \mathrm{~g})$ of Thai pangus in monoculture and moderate growth (398.25 g and $383.28 \mathrm{~g}$ ) in polyculture with carps and prawn using $20 \%$ protein diet from a culture period of 7.5 months. Chuapoehuk \& Pothisoong (1983) reported that a diet having 25\% protein was the best for optimum growth of Thai pangus. Mollah \& Sarder (1991) reported that supplemental feeds containing $20-30 \%$ crude protein in different combinations gave significant growth of this species cultured in cages and ponds. In case of rohu, $0.93 \%$ day ${ }^{-1}$ SGR with final individual weight $717 \mathrm{~g}$ was achieved though higher crude protein level (32\% for fry and $28 \%$ for adult) was supplied and maximum growth (770g) with SGR $0.95 \%$ day ${ }^{-1}$ was gained when moderate crude protein level (30 \% for fry and 26\% for adult) was used. From this it can be concluded that unlikely rohu the growth of Thai pangus was significantly influenced in a regular fashion by feed protein level. About 52g difference in average final individual body weight with $0.02 \%$ day ${ }^{-1}$ difference in SGR of Thai pangus was observed between $T_{1}$ and $T_{3}$ (Table 4) where protein level difference was $4.10 \%$ (Table 1 ).

The survival rate of Thai pangus was $94-97 \%$ in all the experimental treatments (Table 4). The survival rate was about $100 \%$ in cemented cisterns found by Haroon \& Hossain (2001) and 94\%-96\% in earthen ponds as reported by Maniruzzaman (2001). So the survival rate was found not to be influenced by different diets. Moreover important water quality parameters were monitored fortnightly and the values were found to be within the recommended range (Table 3). In $T_{1}, T_{2}$ and $T_{3}$ the Feed conversion ratio (FCR) were 2.3, 2.1 and 1.96 respectively (Table 4). The highest FCR value (2.3) was recorded in $T_{1}$ which indicates that the supplied feed was not as good in quality as it could meet up all the nutrient requirements to produce higher yield of Thai pangus. Where as, the lowest FCR value (1.96) was found in $T_{3}$ which indicates that lower amount of feed was needed to produce one unit of fish biomass. So the lower the FCR is, the better the efficiency (of conversion into final product) of the feed is and such a type of feed in the present experiment was the Saudi Bangla Fish Feed $\left(F_{3}\right)$. But this $F_{3}$ (used in $T_{3}$ ) did not reflect the cost effectiveness or the economic viability of the feeding program (Figure 1).

Table 3. Hydrographical parameters of the treatment ponds during the study period

\begin{tabular}{|c|c|c|c|c|}
\hline Parameters & $\mathbf{T}_{1}$ & $\mathbf{T}_{2}$ & $\mathbf{T}_{3}$ & $\begin{array}{c}\text { Recommended } \\
\text { range }\end{array}$ \\
\hline & $18-34.8$ & $18-33$ & $20-32$ & $\begin{array}{c}20-35 \\
\text { (Choudhury,2000) }\end{array}$ \\
\hline $\begin{array}{l}\text { Transparency } \\
(\mathrm{cm})\end{array}$ & $15-26$ & $16-25$ & $17-24$ & $\begin{array}{c}25-35 \\
(\text { Sarker,2000) }\end{array}$ \\
\hline Depth (m) & $1.2-1.7$ & $1.0-1.5$ & $1.2-1.7$ & $\begin{array}{r}1.2 \\
\text { (Sarke }\end{array}$ \\
\hline $\begin{array}{l}\text { Dissolve } \\
\text { Oxygen (mg/l) }\end{array}$ & $4.2-7.5$ & 4.2-7.4 & $5.5-7.4$ & $\begin{array}{c}5.0-8.0 \\
\text { (Sarker,2000) }\end{array}$ \\
\hline $\mathrm{pH}$ & 7.3-8.9 & 7.4-8.6 & 7.2-8.6 & $\begin{array}{c}6.7-8.6 \\
\text { (Andrewetal, 1972 }\end{array}$ \\
\hline
\end{tabular}

Table 4. Growth performance of the experimental fishes estimated in three respective treatments of $T_{1}$, $\mathrm{T}_{2}$ and $\mathrm{T}_{3}$

\begin{tabular}{l|c|c|c|c|c|c}
\hline Treatments & \multicolumn{2}{|c|}{$\mathbf{T}_{1}$} & \multicolumn{2}{c|}{$\mathbf{T}_{2}$} & \multicolumn{2}{c}{$\mathbf{T}_{3}$} \\
\hline Species & $\begin{array}{c}\text { Thai } \\
\text { pangus }\end{array}$ & Rohu & $\begin{array}{c}\text { Thai } \\
\text { pangus }\end{array}$ & Rohu & $\begin{array}{c}\text { Thai } \\
\text { pangus }\end{array}$ & Rohu \\
\hline $\begin{array}{l}\text { No. of fry } \\
\text { released }\end{array}$ & 24700 & 4940 & 24700 & 4940 & 24700 & 4940 \\
\hline $\begin{array}{l}\text { No. of fish } \\
\text { harvested }\end{array}$ & 23465 & 3903 & 23218 & 4100 & 23959 & 3952 \\
\hline $\begin{array}{l}\text { Survival } \\
\text { Rate (\%) }\end{array}$ & 95 & 79 & 94 & 83 & 97 & 80 \\
\hline FCR & 2.3 & 2.3 & 2.1 & 2.1 & 1.96 & 1.96 \\
\hline $\begin{array}{l}\text { Avg. final } \\
\text { wt. (g) }\end{array}$ & 820 & 710 & 846 & 770 & 872 & 717 \\
\hline $\begin{array}{l}\text { SGR (\% } \\
\text { day }{ }^{-1} \text { ) }\end{array}$ & 1.58 & 0.93 & 1.59 & 0.95 & 1.60 & 0.93 \\
\hline
\end{tabular}

However, the FCR values in all the three treatments were more or less similar to those that were found by other scientists worked on Thai pangus. In cage culture of Thai pangus, Azimuddin (1998) found the FCR value within 1.73-2.04 in three months and Halder and Jahan (2001) found the FCR value within 2.96-3.09 in 5 months. Haroon and Shanta (2001) reported an FCR range of 2.64 to 3.64 in a culture period of 12 months in cemented cisterns. Maniruzzaman (2001) cultured P. sutchi in pond and cage for nine months and found the FCR value as 6 and 8 respectively. Ahmed et al. (1996) compared the effect of three supplementary feeds on $P$. pangasius culture feasibility for three months in earthen pond, and found the FCR as 5.30, 5.75 and 7.5.

The Fig 1 and Fig 2 exhibit growth curves of the experimental fish biomass. Using protein rich commercial feed $F_{3}$ (Saudi-Bangla Feed), on an average $52 \mathrm{~g}$ more growth of Thai pangus was achieved than Hand-made feed $\left(F_{1}\right)$, and $26 \mathrm{~g}$ more growth than Sunney Feed $\left(\mathrm{F}_{2}\right)$. The growth curve of Thai pangus shows a typical increasing trend of SGR and final weight of fish along with the increase of feed protein level. But the growth curve of rohu differs from that of Thai pangus interrupting the typical trend in $\mathrm{T}_{2}>\mathrm{T}_{3}>\mathrm{T}_{1}$ fashion. It might be due to some external factors which affected growth of rohu in $\mathrm{T}_{2}$ than in $\mathrm{T}_{3}$ though the highest (32\% for fry and $28 \%$ for adult $\%)$ protein level was used in $\mathrm{T}_{3}$.

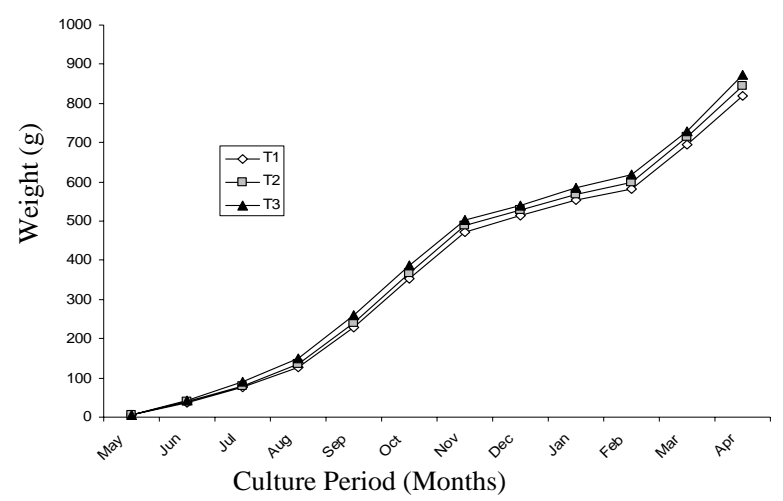

Fig 1. Growth trend of $P$. hypophthalmus over the culture period under three different feed treatments 


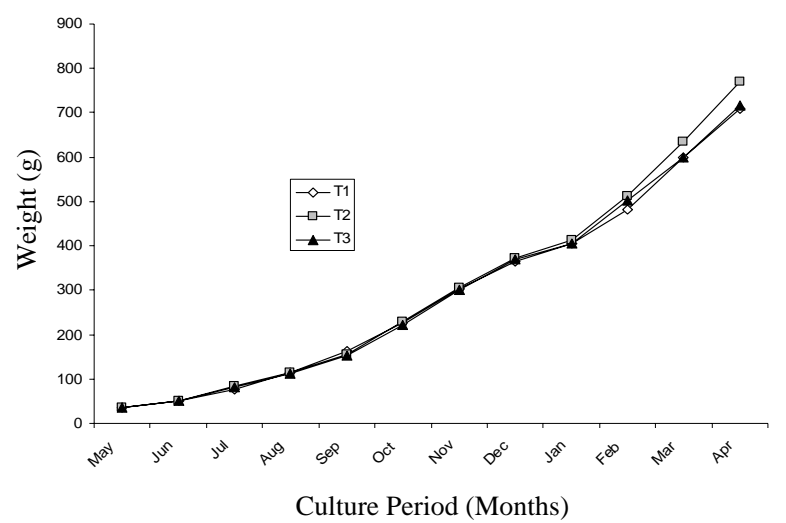

Fig 2. Growth trend of $L$. rohita over the culture period under three different feed treatments

\section{Conclusion}

It was evidenced from the present study that the growth of fish biomass varied from treatment to treatment due to the effect of different types of feed applied. Thai pangus responded towards higher growth with the increasing protein level of the diet applied to different treatments and highest specific growth rate (SGR) $1.60 \%$ day $^{-1}$ was achieved in $\mathrm{T}_{3}$ where protein level was $32 \%$. But it is recommended that the quality and cost efficacy of feed should be considered along with its protein level to obtain a profitable growth of Thai pangus polyculture.

\section{References}

Aguru, P. 1970. Cage culture of Plasawai (Pangasius suchi, Fowler). Thai J. Agr. Sci., 3: 57-65.

Ahmed, G. U., Sarder, M. R. I. \& Kibria, M.G. 1996. Culture feasibility of pangus (Pangasius pangasius Ham.) in earthen ponds with different supplemental diets. Bangladesh $J$. Fish., 19(1-2): 23-27.

Ahmed, M.N.U. 2005. Fisheries sector in the economy of Bangladesh and its potential development (Published in Bengali) In: Souvenir of National Fish Fortnight (Matsya Pokkhya) 2005. Department of Fisheries, Dhaka, Bangladesh. pp. 11-15.

Andrew, A.W., Moore, K. D. \& LeRoy, A.C. 1972. A Guide to the Study of Environmental Pollution. Prentice-Hall. Inc., Englewood Cliffs, New Jersey. pp. 23-32.

Azimuddin, K.M. 1998. Effect on stocking density on the growth of Thai pangus, Pangasius sutchi (Folwer) in net cage by using formulated diet. Unpublished MS Thesis, Bangladesh Agricultural University, Mymensingh, Bangladesh.

Bardach, J.E., Ryther, J.H. \& Mclarncy, W.O. 1972. Aquaculture: The Farming and Husbandry of Fresh water and Marine Organisms. John Wiley and Sons. New York. pp. 206-210.

BFRI \& BARC. 2001. Effect of stocking density on the growth and production of Thai pangus (Pangasius sutchi) in cages in pond condition. Final report on post flood rehabilitation and adaptive research support project. Published by Bangladesh Fisheries Research Institute and Bangladesh Agricultural Research Council, Dhaka. pp. 48- 51.

Choudhury, H. A. 2000. Polyculture System of Thai pangus at Alpha Fisheries, Trishal, Mymensingh. Unpublished MS Thesis, Bangladesh Agricultural University, Mymensingh, Bangladesh.
Chuapoehuk, W \& Pothisooing, T. 1983. Protein requirement of catfish P.sutchi (Fowler). In: Finfish Nutrition in Asia Cho, C.Y., Cowey, C.B. \& Watanabe, T. (eds.).. Proc. Asian Finfish Nutrition Workshop held in Singapore, 23-26 August 1993, International Development Research Center, Ottawa, Canada. pp. 103-122.

Diana, J. S., Lin, C. K. \& Jaiyen, K. 1994. Supplemental feeding of tilapia in fertilized ponds. J. World Aquaculture Soc. 25: 497-506.

DoF. 2000. Commercial Basis of Pangus Culture-Farmers' Guide (Published in Bengali). Published by Department of Fisheries, Dhaka, Bangladesh.

Green, B. W. 1992. Substitution of organic manure for pelleted feed in tilapia production. Aquaculture, 101: 213-222.

Haldar, G.C. \& Jahan, D.A. 2001. Polyculture of pangus with carp at low density in a farmer's pond. Final report on post flood rehabilitation and adaptive research support project. Bangladesh Fisheries Research Institute, Chandpur and Bangladesh Agricultural Research Council, Dhaka. pp. 66-74.

Haque, M. E. 2005. Brief History of Small and Extinct Fishes of Bangladesh (Published in Bengali). Department of Fisheries, Dhaka, Bangladesh.

Haroon, A.K.Y. \& Hossain, M.R.A. 2001. Studies on the polyculture of Pangasius sutchi (Fowler) in cemented cisterns. Final report on post flood rehabilitation and adaptive research support project. Bangladesh Fisheries Research Institute, Chandpur and Bangladesh Agricultural Research council, Dhaka. pp. 12-18.

Haroon, A.K.Y. \& Shanta, M.H.A. 2001. Culture feasibility study of Pangasius sutchi (Fowler) at a high density in the Upazilla Parishad's pond. Final report on post flood rehabilitation and adaptive research support project. Bangladesh Fisheries Research Institute, Chandpur and Bangladesh Agricultural Research council, Dhaka. pp. 6365.

Huq, K.A., Islam, M.S. \& Rahman, M.A., 2004. Suitable species composition in the polyculture technique of Thai pangus (Pangasius hypophthalmus) with carps and prawn. Bangladesh Journal of Fisheries: 27: 13- 17.

Lutz, C. G. 2003. World Polyculture: Principles, Practices, Problems and Promise. Aquaculture Magazine, 29: 34-39.

Maniruzzaman, M. 2001. Polyculture of Pangsius sutchi with carps at a fish farm of Saleque Enterprize, Namopara, Rajshahi. Unpublished MS Thesis, University of Rajshahi, Rajshahi, Bangladesh.

Mollah, M.F.A. \& Sarder, M.R.I. 1991. Effects of supplemental feed on growth and production of pangus (Pangasius pangasius Ham.) in ponds. Prog. Agric., 2(1): 83-87.

Rahman, M.K., Akhter, J.N., Mazid, M.A. \& Haldar, G.C. 1992. Comparision of fingerling growth rates and survival of two Pangasius species. J. Inland Fish. Soc. India, 24 (2): 40-44.

Ricker, W. E. 1975. Computation and interpretation of biological statistics of fish population. Bull. Fisheries Res. Board of Canada, 191: 1-382.

Sarder, M.R.I., Mollah, M.F.A., Ahmad, G.U. \& Kibria, M.G. 1994. Effects of supplemental diets of the growth of Pangus (Pangasius pangasius, Ham.) in nets cages. Bangladesh Agric. J. Fish., 22(2): 303-307.

Sarker, M.T. 2000. Pangus Chash Babosthapana (Management of Pangus culture). Department of Fisheries, Bangladesh. 25 p.

Manuscript received on07.07.2008, accepted on 21.10.2008 